\title{
Chronic hepatitis B and D: prognosis according to Child-Pugh score
}

\author{
Hepatites crônicas B e D: prognóstico segundo escore Child-Pugh \\ Hepatitis crónicas $B$ y D: pronóstico según escore Child-Pugh
}

\section{Marcelo Siqueira de Oliveiral,"l, Romeu Paulo Martins Silva"l', Suiane da Costa Negreiros do Valle", Elisabeth Níglio de Figueiredoiv ${ }^{\text {, Dayana Fram }}{ }^{v}$}

'Universidade Federal de São Paulo, Paulista Nursing School, Postgraduate Program in Nursing. São Paulo, Brazil.

"Universidade Federal do Acre, Multidisciplinary Center of Cruzeiro do Sul. Cruzeiro do Sul, Acre, Brazil.

"' Universidade Federal do Acre, Center for Health and Sports Sciences. Rio Branco, Acre, Brazil.

Iv Universidade Federal de São Paulo, Paulista Nursing School, Department of Collective Health Nursing. São Paulo, Brazil.

v Universidade Federal de São Paulo, Paulista Nursing School, Department of Clinical and Surgical Nursing. São Paulo, Brazil.

\section{How to cite this article:}

Oliveira MS, Silva RPM, Valle SCN, Figueiredo EN, Fram DS. Chronic hepatitis B and D: prognosis according to Child-Pugh score. Rev Bras Enferm [Internet]. 2017;70(5):1048-53. [Thematic Edition "Good Practices: Fundamentals of Nursing work in the construction of a democratic society"] DOI: http://dx.doi.org/10.1590/0034-7167-2016-0205

\section{Submission: 08-31-2016 Approval: 03-17-2017}

\section{ABSTRACT}

Objective: compare chronic hepatitis B patients to those superinfected with hepatitis D virus, according to Child-Pugh score regarding disease severity. Method: retrospective descriptive study, performed with 59 patients followed in the ambulatory, of which $22(37.3 \%)$ were chronically infected with hepatitis B virus (Group HBV) and 37 (62.7\%) superinfected with Delta virus (Group HBV + HDV); variables of sex, age and items of Child-Pugh score were collected by consulting medical records. Results: out of the patients, $57.6 \%$ were male, with a mean age of 30.5 years. Score A, which indicates lesser severity, was found in $100 \%$ of group HBV and $78.4 \%$ of group HBV + HDV. Score B, which indicates greater severity, was found only in group HBV + HDV in $21.6 \%$ of the patients. Conclusion: by means of the Child-Pugh score, it was observed that patients with superinfection by HDV tended to present a worse prognosis.

Descriptors: Hepatitis B; Hepatitis D; Prognosis; Gastroenterology; Infectology.

\section{RESUMO}

Objetivo: comparar os pacientes com hepatite B crônica com superinfectados pelo vírus $\mathrm{D}$ segundo escore de Child-Pugh quanto à gravidade da doença. Método: estudo descritivo retrospectivo, realizado com 59 pacientes acompanhados em ambulatório, sendo $22(37,3 \%)$ cronicamente infectados pelo vírus da hepatite B (Grupo VHB) e 37 (62,7\%) com superinfecção por vírus Delta (Grupo VHB + VHD); foram coletadas variáveis quanto ao sexo, idade e referentes ao escore de Child-Pugh por meio de consulta a prontuários. Resultados: entre os pacientes $57,6 \%$ era do sexo masculino, com idade média de 30,5 anos. O escore A, que indica menor gravidade, foi encontrado em $100 \%$ do grupo VHB e $78,4 \%$ do grupo VHB + VHD. O escore B, que indica maior gravidade, foi encontrado apenas no grupo VHB + VHD em 21,6\% dos pacientes. Conclusão: por meio do escore de Child-Pugh, observou-se que os pacientes com superinfecção por VHD tendem a apresentar pior prognóstico.

Descritores: Hepatite B; Hepatite D; Prognóstico; Gastroenterologia; Infectologia.

\section{RESUMEN}

Objetivo: comparar los pacientes con hepatitis B crónica con superinfectados por el virus D según escore de Child-Pugh cuanto a la gravedad de la enfermedad. Método: estudio descriptivo retrospectivo, realizado con 59 pacientes acompañados en ambulatorio, siendo $22(37,3 \%)$ crónicamente infectados por el virus de hepatitis B (Grupo VHB) y $37(62,7 \%)$ con superinfección por virus Delta (Grupo VHB + VHD); fueron colectadas variables cuanto al sexo, edad y referentes al escore de Child-Pugh por medio de consulta a prontuarios. Resultados: entre los pacientes $57,6 \%$ era de varones, con edad media de 30,5 años. El escore A, que indica menor gravedad, fue encontrado en $100 \%$ del grupo $\mathrm{VHB}$ y $78,4 \%$ del grupo VHB + VHD. El escore B, que indica mayor gravedad, fue encontrado apenas en el grupo VHB + VHD en 21,6\% de los pacientes. Conclusión: por medio del escore de Child-Pugh, se observó que los pacientes con superinfección por VHD tienden a presentar peor pronóstico.

Descriptores: Hepatitis B; Hepatitis D; Pronóstico; Gastroenterología; Infección. 


\section{INTRODUCTION}

Chronic hepatitis due to B virus (HBV) and those associated with D virus (HDV) constitute a severe public health problem throughout the world, since it is a chronic condition resulting in constant demands on the health services, as well as considerable loss in the quality of life among infected patients, faced with the characteristics of morbidity and mortality related to these infections ${ }^{(1-3)}$.

Both viruses are transmitted parenterally and capable of leading to the development of chronic hepatic disease with many evolutionary complications, such as pictures of polyarthritis, glomerulonephritis, rheumatic polymyalgia, cryoglobulinemia, among others and especially for hepatic cirrhosis and hepatocellular carcinoma $(\mathrm{HCC})^{(4)}$.

This type of infection presents a global distribution, where studies have suggested that HBV has a contamination potential that could affect approximately one third of the total world population. It has been estimated that there are in the region of 300 to 400 million chronic carriers, of which 15 to 20 million could present concomitant infection by HDV ${ }^{(2,5-7)}$.

In Brazil, a national study revealed differences in the epidemiological patterns between regions, as well as estimating that $15 \%$ of the population has already come into contact with HBV, a condition necessary for infection by HDV and that chronic hepatitis $\mathrm{B}$ already affects approximately $1 \%$ of the population ${ }^{(8)}$.

It is important to report that infection by HDV is considered a co-infection when it occurs in the primary (acute) phase of HBV and to be a superinfection when occurring in chronic hepatitis B carriers ${ }^{(4,9)}$.

HDV has a world distribution with varying prevalence rates. In Central Europe the disease affects $47.6 \%$ of AgHBs positive patients in Romania and $13.9 \%$ in Hungary. In Africa, the infection principally affects the occidental and central countries, varying from $1.3 \%$ in Nigeria up to $66 \%$ in Gabon. In Egypt infection by HDV is an estimated $20 \%$. In Asia, the prevalence could reach $66.7 \%$ in Taiwan, while in Mongolia $82 \%$ of HBV infected patients presenting advanced hepatic disease are superinfected with HDV ${ }^{(10)}$.

In South America, HDV superinfection is predominant in the Amazon Basin, notably in the Brazilian Western Amazon, where anti-HDV seropositivity could reach up to $85 \%$ of the AgHBs positive patients ${ }^{(2,10-11)}$.

Early evolution into the more severe complications of hepatic disease has been systematically related to HDV superinfection $^{(7,12-13)}$. This represents a serious health problem in the context of the Brazilian Occidental Amazon, principally due to the relationship between the infection and exacerbation of symptoms ${ }^{(14)}$.

Complications arising from chronic HBV infection represent one of the most common indications for kidney transplantation over the previous 10 years, while approximately $25 \%$ of chronic HBV carriers can develop cirrhosis or HCC. Superinfection with HDV, a known risk factor for terminal hepatic disease, also has limited treatment options with liver transplantation remaining the only option ${ }^{(15)}$.

In Brazil 2006, the Ministry of Health published Decree $n^{\circ}$ 1.160, after which the MELD-PELD (Model for End-stage Liver
Disease - Pediatric End-stage Liver Disease) score became used to estimate the prognosis recommended for indication of hepatic transplantation in the Sistema Único de Saúde [Single Health System]. Later, Decree MS no 1.160/2006 was revoked by Decree $n^{\circ}$. 2.600, dated 21 October 2009, also from the Health Ministry, which reformulated the technical regulations of the national transplantation system and maintained the recommendation to use the MELD-PELD score for this purpose $\mathrm{e}^{(16-17)}$.

Despite the specific indication, Brazilian legislation does not impede the use of other mechanisms for the prognostic estimator. In this sense, the Secretary of Health Surveillance and the Department of STDs, HIV and viral hepatitis of the Ministry of Health have recommended, since 2010, via the Clinical and Therapeutic Guidelines for the Treatment of Chronic Hepatitis B Virus and co-infections, the use of the Child-Pugh score as a prognostic estimator, inclusively when considering the indication for liver transplantation $^{(18)}$. The Child-Pugh score is considered to be a simple and easily adapted instrument, that is capable of estimating the health conditions of patients with cirrhosis and $\mathrm{HCC}^{(19-20)}$.

Thus, considering the elevated endemic pattern of HBV infection and HDV superinfection in the Brazilian Western Amazon, as well as the exacerbation of signs and symptoms and early evolution to final stages of HDV-related chronic hepatitis ${ }^{(12,21)}$, in addition to the scarcity of scientific studies realized in the Brazilian Western Amazon on this subject ${ }^{(14,22)}$, the present study aimed to compare patients with chronic hepatitis B and those superinfected with D-virus according to the Child-Pugh score for disease severity.

\section{METHOD}

\section{Ethical aspects}

The research was approved by the Research Ethics Committee of the Universidade Federal de São Paulo - Unifesp on 21 December, 2012.

\section{Design, study location and period}

A retrospective descriptive study was performed from June to December 2014, at the Sanitary Dermatology Hospital in the city of Cruzeiro do Sul - Acre, Brazilian Western Amazon, which is a regional reference center for the treatment of patients diagnosed with chronic hepatitis due to HBV and superinfection with HDV; 522 patients were registered in the service.

\section{Population or sample; inclusion and exclusion criteria}

The study population comprised all patients diagnosed with chronic hepatitis B and those superinfected with HDV, whose clinical and laboratory follow-up began in 2007 and continued until 2012, amounting to a total of 134. Patients were excluded that presented a diagnosis of HIV, hepatitis C infection, malignant neoplasia unrelated to infectious liver disease, autoimmune disease, chronic decompensated conditions, and patients who had not performed all laboratory tests necessary to calculate the ChildPugh score. After applying the above mentioned criteria, 38 patients with chronic hepatitis B diagnosis and 37 superinfected with HDV were excluded because they presented one or more of the exclusion criteria. A total of 59 patients were included in the study. 


\section{Study protocol and data collection}

The 59 patients selected to participate in the study were divided into two groups: patients chronically infected with virus $B$ (Group HBV), comprising 22 individuals; and patients superinfected with HDV (Group HBV + HDV), formed by 37 patients.

Data collection was realized by consultation of medical records; the collection instrument used included the following variables: sex, age, serum bilirubin, serum albumin, prothrombin time (INR), and records of clinical conditions such as ascites and neurological disorders related to chronic liver disease due to HBV and HDV.

The following clinical and laboratory data were used to calculate the Child-Pugh score: serum bilirubin and albumin, presence or absence of ascites, presence or absence of neurological disorder, and prothrombin time. The score values range from 5 to 15 points, as shown in Chart 1 , and are classified from $A$ to $C$ (Score A, 5 to 6 points, B, 7 to 9 and C, 10 to 15). Patients with Score B, i.e. $\geq 7$, present a poor prognosis and should be evaluated regarding their indication for liver transplantation ${ }^{(18,23)}$.

Chart 1 - Child-Pugh score ${ }^{(18,23)}$

\begin{tabular}{|c|c|c|c|}
\hline $\begin{array}{l}\text { Cirrhosis - Child- } \\
\text { Pugh classification } \\
\text { factor }\end{array}$ & 1 point & 2 points & 3 points \\
\hline $\begin{array}{l}\text { Serum bilirubin } \\
\mu \mathrm{mol} / \mathrm{l}(\mathrm{mg} / \mathrm{dl})\end{array}$ & $\begin{array}{l}<34 \\
(<2.0)\end{array}$ & $\begin{array}{c}34-51 \\
(2.0-3.0)\end{array}$ & $\begin{array}{l}>51 \\
(>3.0)\end{array}$ \\
\hline $\begin{array}{l}\text { Serum albumin } \\
g / \mathrm{g}(\mathrm{g} / \mathrm{dl})\end{array}$ & $\begin{array}{l}>35 \\
(>3.5)\end{array}$ & $\begin{array}{c}30-35 \\
(3.0-3.5)\end{array}$ & $\begin{array}{l}<30 \\
(<3.0)\end{array}$ \\
\hline Ascites & None & $\begin{array}{c}\text { Easily } \\
\text { controlled }\end{array}$ & $\begin{array}{c}\text { Poorly } \\
\text { controlled }\end{array}$ \\
\hline $\begin{array}{l}\text { Neurological } \\
\text { alterations }\end{array}$ & None & Minimum & $\begin{array}{c}\text { Advanced } \\
\text { coma }\end{array}$ \\
\hline $\begin{array}{l}\text { Prothrombin time } \\
\text { (too slowly in } \\
\text { seconds) } \\
\text { INR* }\end{array}$ & $\begin{array}{l}0-4 \\
<1.7\end{array}$ & $\begin{array}{c}4-6 \\
1.7-2.3\end{array}$ & $\begin{array}{l}>6 \\
>2.3\end{array}$ \\
\hline
\end{tabular}

Note: *INR: International Normalized Ratio

\section{Statistical analysis}

The data was tabulated in a Microsoft Excel worksheet (Office 2010) and described by absolute and relative frequency. For statistical analysis of the categorical variables, the chisquare test $\left(x^{2}\right)$ was used. Throughout statistical analysis, the $5 \%$ significance level $(\alpha=0.05)$ was adopted, that is, results with $p<0.05$ were considered to be statistically significant.

\section{RESULTS}

Of the 59 patients comprising the study population, $37.3 \%$ $(\mathrm{n}=22)$ were in the HBV group and $62.7 \%(\mathrm{n}=37)$ in group $\mathrm{HBV}+\mathrm{HDV}$. The majority of subjects were male, representing $57.6 \%$ of the population. There was a similar distribution of this variable between the groups, since males represented $55 \%$ and $59 \%$ of the medical records in groups HBV and HBV + HDV, respectively.
As for age, patients in the HBV group presented a mean of 30 years, similar to the mean age of the HBV + HDV group, which was 31 . The mean for the total population was 30.5 years.

Regarding the Child-Pugh score, for both groups classification A (5-6) presented a higher frequency, representing 100\% of those belonging to the HBV group and $78.4 \%$ of those who composed the HBV + HDV group. Only in the HBV + HDV group, results with a B score (7-9) were obtained, corresponding to $21.6 \%$ of the individuals in the group. None of the patients had scores equivalent to classification C (10-9). There was no significant difference between the groups when compared to the scores, regardless of the classification (see Table 1).

Table 1 - Classification of Child-Pugh score, in the groups with hepatitis $B$ virus (HBV) and superinfected with hepatitis D virus (HBV + HDV), Cruzeiro do Sul, Acre, Brazil, 2007 to 2012

\begin{tabular}{cccccccccc}
\hline \multirow{2}{*}{ Classification } & \multirow{2}{*}{ Score } & \multicolumn{2}{c}{ HBV } & \multicolumn{3}{c}{ HBV + HDV } & & & \\
\cline { 2 - 6 } & & $\mathbf{n}$ & $\%$ & $\mathbf{n}$ & $\%$ & $\mathbf{n}$ & $\%$ & $\mathbf{p}$ \\
\hline \multirow{2}{*}{$\mathrm{A}$} & 5 & 21 & 95.5 & 22 & 59.5 & 43 & 72.9 & 0.12 \\
& 6 & 1 & 4.5 & 7 & 18.9 & 8 & 13.6 & 0.15 \\
B & 7 & 0 & 0.0 & 3 & 8.1 & 3 & 5.1 & 0.18 \\
& 8 & 0 & 0.0 & 2 & 5.4 & 2 & 3.4 & 0.28 \\
& 9 & 0 & 0.0 & 3 & 8.1 & 3 & 5.1 & 0.18 \\
\multirow{2}{*}{ Total } & -- & 22 & 100.0 & 37 & 100.0 & 59 & 100.0 & - \\
\hline
\end{tabular}

Note: $H B V$ - Hepatitis B virus; HDV - Hepatitis D virus.

According to the findings, only group HBV $+\mathrm{HDV}$ presented B scores (7-9), indicating a poor prognosis. Thus, when a comparison was made according to the distribution of scores A (indicative of good prognosis) and B (indicative of poor prognosis), a significant difference was observed between the groups (Table 2).

Table 2 - Comparison of the Child-Pugh score classification $A$ and $B$ between the groups with hepatitis B virus (HBV) and superinfected with hepatitis $D$ virus (HBV + HDV), Cruzeiro do Sul, Acre, Brazil, 2007 to 2012

\begin{tabular}{lccc}
\hline & \multicolumn{2}{c}{ Classification } & \\
\cline { 2 - 3 } & $\begin{array}{c}\mathbf{A} \\
\mathbf{n}(\%)\end{array}$ & $\begin{array}{c}\mathbf{B} \\
\mathbf{n}(\%)\end{array}$ & $\mathbf{p}$ \\
\hline Group HBV & $22(43.13 \%)$ & $0(-)$ & 0.02 \\
Group HBV + HDV & $29(56.86 \%)$ & $8(100.0)$ & \\
Total & 51 & 8 & \\
\hline
\end{tabular}

Note: Score $A=5-6$ points; Score $B=7-9$ points; $H B V$ - Hepatitis $B$ virus; HDV - Hepatitis $D$ virus.

\section{DISCUSSION}

In the present study, $62.7 \%$ of the patients belonged to group HBV + HDV. With greater frequency, studies have reported a mean proportion of associated infection between $5 \%$ and $30 \%$ of 
patients with $\mathrm{HBV}^{(7,23)}$. In the Amazon region, presence of HDV antibodies (anti-HD) has already been estimated to be up to $34 \%$ of HBV carriers $^{(24)}$.

However, the estimates are not exact and often not even close when considering the peculiarities inherent to the various communities in the region. An example of this is the result of a multicenter study of patients in outpatient care in the Western Amazon, which revealed a HDV infection rate ranging from $47 \%$ to $65 \%$ of $\mathrm{AgHB}$ positive patients; values close to the results of this study ${ }^{(2)}$.

However, it is necessary to emphasize that there have been few studies on the prevalence of HDV in Brazil(1). In addition, estimates of HDV infection are variable and may sometimes not correspond to the distribution of chronic HBV-infected patients ${ }^{(10)}$.

Another aspect of the study concerns the sex and age of patients. HBV infection and HDV superinfection are often more endemic among males. An epidemiological study of molecular characterization carried out in the Brazilian Western Amazon presented a prevalence of $53.8 \%$ in men $^{(24)}$, a value similar to the $56.7 \%$ observed in the population of the present study. When the age of the infected subjects was considered, two studies in the region also revealed a predominance of infection in young adults with mean age varying from $21.3^{(24)}$ to $40^{(2)}$ years.

Regarding the calculation and classification of the ChildPugh score, it was observed that the majority of patients, in both groups, presented classification $A$, indicative of a more favorable prognosis, when compared with classifications $B$ and C. Patients with a score between 5 And 6, that is type A, present better survival rates ${ }^{(19)}$.

When the groups were compared in relation to classification $A$ and $B$, the result showed a statistically significant difference ( $p=0.02)$, and the HBV + HDV group was the only one to record classification $\mathrm{B}$ scores. The $\mathrm{B}$ score is related to complications in hepatic function, such as cirrhosis and $\mathrm{HCC}^{(19)}$, and is an indication of poor prognosis ${ }^{(18)}$.

The observation that the prognostic estimate was worse among patients with HDV superinfection is in agreement with the results of studies available in the scientific literature that associate HDV superinfection with a greater severity of chronic liver disease characterized by accelerated evolution to the end-stages of the pathological process ${ }^{(12,21,25)}$. It is noteworthy that these characteristics have already been reported in the Brazilian Western Amazon ${ }^{(1)}$.

In the geographical context, the Amazon region registers a high endemic pattern for HBV and HDV infections, characterized by a series of difficulties in relation to diagnosis and control, due to its vast territorial dimension composed by municipalities dispersed in the forest with difficult access, as well as the diverse ethnic composition of people affected ${ }^{(2)}$.

\section{Study Limitations and Contributions to the Nursing, Health, or Public Policy Area}

This study has contributed to the advancement in knowledge regarding the prognosis of patients with chronic hepatitis B and HDV superinfection, reaffirming the association between HDV superinfection and greater severity of liver disease. The use of prognostic estimation methods is useful for health care and nursing practice, as it allows nurses at any level of care to carry out individualized and consequently better quality care planning, due to the possibility of estimating future health conditions. Regarding the limitations of the study, it was performed in only one health care center.

\section{CONCLUSION}

The study showed that HDV superinfection, as already reported in the scientific literature, was once again related to a poor prognosis, especially in the context of the Brazilian Western Amazon, where health technologies are scarce.

In addition, it is important to report that use of the Child-Pugh score as a mechanism to estimate the prognosis of patients with chronic hepatitis due to HBV and HDV superinfection, given its basic characteristics, requires multiple factors that range from the availability of technologies for the performance of the specific tests to a thorough clinical examination by a specialist-a condition that is scarce in many communities within the Western Amazon.

Finally, the use of the score allows an evaluation of the clinical conditions of patients with chronic liver disease due to HBV and superinfection with HDV. The prognosis obtained can be used as a parameter for therapeutic management of patients, prescription of priority care and indication for liver transplantation.

\section{REFERENCES}

1. Barros LMF, Gomes-Gouvêa MS, Pinho JRR, Alvarado-Mora MV, Dos Santos A, Mendes-Corrêa MCJ, et al. Hepatitis Delta virus genotype 8 infection in Northeast Brazil: inheritance from African slaves?. Virus Res [Internet]. 2011 [cited 2016 Apr 17];160(1-2):333-9. Available from: http://ac.els-cdn.com/S0168170211002589/1-s2.0-S0168170211002589-main. pdf?_tid =f5c9d3d6-6d54-11e6-bc80-00000aab0f6b\&acdnat=1472412415_59c14e938a6aa132757adeeeb1be73ec

2. Crispim MAE, Fraiji NA, Campello SC, Schriefer NA, Stefani MMA, Kiesslich D. Molecular epidemiology of hepatitis B and hepatitis delta viruses circulating in the Western Amazon region, North Brazil. BMC Infect Dis [Internet]. 2014 [cited 2016 Apr 20];14:94. Available from: http://bmcinfectdis.biomedcentral.com/articles/10.1186/1471-2334-14-94

3. Niederau C. Chronic hepatitis B in 2014: Great therapeutic progress, large diagnostic deficit. World J Gastroenterol [Internet]. 2014 [Cited 2016 Apr 17];20(33):11595-617. Available from: http://www.ncbi.nlm.nih.gov/pmc/articles/PMC4155353/pdf/WJG20-11595.pdf

4. Silva AL, Vitorino RR, Esperidião-Antonio V, Santos ET, Santana LA, Henriques BD, et al. Hepatites virais: B, C e D: atualização. Rev Soc Bras Clín Méd [Internet]. 2012 [cited 2016 Apr 17]; Available from: http://files.bvs.br/upload/S/1679-1010/2012/v10n3/ a2889.pdf 
5. Lopes TGSL, Schinoni MI. Aspectos gerais da hepatite B. R. Ci. med. bio. [Internet]. 2011 [cited 2016 Apr 17];10(3):337-44. Available from: http://www.portalseer.ufba.br/index.php/cmbio/article/view/5899/4251

6. Mello FCA, Fernandes CA, Gomes SA. Antiviral therapy against chronic hepatitis B in Brazil: high rates of lamivudine resistance mutations and correlation with HBV genotypes. Mem Inst Oswaldo Cruz [Internet]. 2012 [cited 2016 Apr 22];107(3):317-25. Available from: http://www.scielo.br/pdf/mioc/v107n3/05.pdf

7. Wedemeyer H, Manns MP. Epidemiology, pathogenesis and management of hepatitis D: update and challenges ahead. Nat Rev Gastroenterol Hepatol [Internet]. 2010 [cited 2016 Apr 17];7(1):31-40. Available from: http://www.nature.com/nrgastro/journal/ v7/n1/abs/nrgastro.2009.205.html

8. Martins AMEBL, Costa FM, Ferreira RC, Santos-Neto PE, Magalhaes TA, Sá MAB, et al. Fatores associados à imunização contra Hepatite B entre trabalhadores da Estratégia Saúde da Família. Rev Bras Enferm [Internet]. 2015 [cited 2016 Apr 22];68(1):84-92. Available from: http://www.scielo.br/pdf/reben/v68n1/0034-7167-reben-68-01-0084.pdf.

9. Alvarado-Mora MV, Romano CM, Gomes-Gouvêa MS, Gutierrez MF, Carrilho FJ, Pinho JRR. Dynamics of Hepatitis D (delta) virus genotype 3 in the Amazon region of South America. Infect Genet Evol [Internet]. 2011 [cited 2016 May 10];11(6):1462-8. Available from: http://www.sciencedirect.com/science/article/pii/S1567134811002085

10. Alfaiate D, Dény P, Durantel D. Hepatitis delta virus: From biological and medical aspects to current and investigational therapeutic options. Antiviral Res [Internet]. 2015 [cited 2016 May 12];122:112-29. Available from: http://www.sciencedirect.com/ science/article/pii/S0166354215001953

11. Villa DDF, Cortes-Mancera F, Payares E, Montes N, Hoz F, Arbelaez MP, et al. Hepatitis D virus and hepatitis B virus infection in Amerindian communities of the Amazonas state, Colombia. Virol J [Internet]. 2015 [cited 2016 Apr 5];12:172. Available from: https://www.ncbi.nlm.nih.gov/pmc/articles/PMC4619413/pdf/12985_2015_Article_402.pdf

12. Braga WSM, Castilho MC, Borges FG, Leão JRDT, Martinho ACS, Rodrigues IS, et al. Hepatitis D virus infection in the Western Brazilian Amazon - far from a vanishing disease. Rev Soc Bras Med Trop[Internet]. 2012 [cited 2016 May 12];45(6):691-5. Available from: http://www.scielo.br/pdf/rsbmt/v45n6/07.pdf

13. Kiesslich D, Crispim MA, Santos C, Ferreira FL, Fraiji NA, Komninakis SV, et al. Influence of Hepatitis B Virus (HBV) Genotype on the Clinical Course of Disease in Patients Coinfected with HBV and Hepatitis Delta Virus. J Infect Dis [Internet]. 2009 [cited 2016 May 22];199(11):1608-11. Available from: http://www.jstor.org/stable/40254910?seq=1\#page_scan_tab_contents

14. Oliveira MS, Valle SDCN, Silva RPM, Figueiredo EN. Hepatite B e a superinfecção por vírus D em pacientes crônicos na Amazônia ocidental brasileira. Rev Epidemiol Control Infec[Internet]. 2015 [cited 2016 Apr 17];5(2). Available from: http://online.unisc. br/seer/index.php/epidemiologia/article/view/5442

15. Ferrarese A, Zanetto A, Gambato M, Bortoluzzi I, Nadal E, Germani G, et al. Liver transplantation for viral hepatitis in 2015. World J Gastroenterol [Internet] 2016 [cited 2016 May 22];22(4):1570. Available from: http://www.wjgnet.com/1007-9327/full/ v22/i4/1570.htm

16. Brasil. Ministério da Saúde. Portaria № 1.160, de 29 de Maio de 2006 (Revogada pela PRT GM/MS no 2.600 de 21.10.2009) [Internet]. Brasília (DF): Ministério da Saúde; 2006 [cited 2016 May 3]. Available from: http://bvsms.saude.gov.br/bvs/saudelegis/ gm/2006/prt1160_29_05_2006_comp.html

17. Brasil. Ministério da Saúde. Portaria № 2.600, de 21 de Outubro de 2009 [Internet]. Brasília (DF): Ministério da Saúde; 2009 [cited 2016 May 3]. Available from: http://bvsms.saude.gov.br/bvs/saudelegis/gm/2009/prt2600 2110 2009.html

18. Brasil. Ministério da Saúde. Secretaria de Vigilância em Saúde. Departamento de DST, AIDS e Hepatites Virais. Protocolo clínico e diretrizes terapêuticas para o tratamento da hepatite viral crônica B e coinfecções [Internet]. Brasília (DF): Ministério da Saúde; 2011 [cited 2016 May 3]. Available from: http://bvsms.saude.gov.br/bvs/publicacoes/protocolo_clinico_diretrizes_terapeuticas_hepatite_viral_b.pdf

19. Okajima C, Arii S, Tanaka S, Matsumura S, Ban D, Ochiai T, et al. Prognostic role of Child-Pugh score 5 and 6 in hepatocellular carcinoma patients who underwent curative hepatic resection. Am J Surg [Internet]. 2015 [cited 2016 Mar 12];209(1):199-205. Available from: http://www.americanjournalofsurgery.com/article/S0002-9610(14)00212-8/abstract

20. Wang YY, Zhong JH, Su ZY, Huang JF, Lu SD, Xiang BD, et al. Albumin-bilirubin versus Child-Pugh score as a predictor of outcome after liver resection for hepatocellular carcinoma: Prediction of outcome after liver resection for hepatocellular carcinoma. Br J Surg [Internet]. 2016 [cited 2016 Mar 12];103(6):725-34. Available from: http://onlinelibrary.wiley.com/doi/10.1002/ bjs.10095/full

21. Romanelli RMC, Faria LC, Monteiro RJGC, Nunes RVP, Duclou CN, Lima AS, et al. Evolução de pacientes submetidos a transplante hepático por hepatites virais. Rev Med Minas Gerais [Internet]. 2015 [cited 2016 Mar 14];25(3):338-5. Available from: http://bases.bireme.br/cgi-bin/wxislind.exe/iah/online/? lsisScript $=$ iah/iah.xis\&src $=$ google\&base $=$ LILACS\&lang $=$ p\&nextAction $=$ Ink\&exprSearch $=763939$ \&indexSearch $=$ ID

22. Wedemeyer H. Re-emerging interest in hepatitis delta: New insights into the dynamic interplay between HBV and HDV. J Hepatol [Internet]. 2010 [cited 2016 Apr 12];52(5):627-9. Available from: http://www.journal-of-hepatology.eu/article/ S0168-8278(10)00037-1/pdf

23. Pugh RNH, Murray-Lyon IM, Dawson JL, Pietroni MC, Willians R. Transection of the oesophagus for bleeding oesophageal varices Br J Surg [internet]. 1973 [cited 2016 Apr 13];60(8):646-649. Available from: https://www.ncbi.nlm.nih.gov/pubmed/4541913 
24. Ghamari S, Alavian SM, Rizzetto M, Olivero A, Smedile A, Khedive A, et al. Prevalence of Hepatitis Delta Virus (HDV) Infection in Chronic Hepatitis B Patients with Unusual Clinical Pictures. Hepat Mon [Internet]. 2013 [cited 2016 Apr 19];13(8):e6731. Available from: http://www.ncbi.nlm.nih.gov/pmc/articles/PMC3787685/pdf/hepatmon-13-08-6731.pdf

25. Castilho MDC, De O, De LG, Di TL, Braga WSM. Epidemiology and molecular characterization of hepatitis B virus infection in isolated villages in the western Brazilian Amazon. Am J Trop Med Hyg [Internet]. 2012 [cited 2016 May 21];87(4):768-74. Available from: https://www.ncbi.nlm.nih.gov/pmc/articles/PMC3516333/pdf/tropmed-87-768.pdf

26. Abbas Z, Hamid S, Qureshi M, Jafri W. Hepatocellular carcinoma in hepatitis D: Does it differ from hepatitis B monoinfection? Saudi J Gastroenterol [Internet]. 2012 [cited 2016 May 12];18(1):18-4. Available from: http://www.saudijgastro.com/temp/ SaudiJGastroenterol18118-6593019_181850.pdf 